\title{
Investigating E-Learning Motivational Strategies of Higher Education Learners against Online Distractors
}

\author{
Ali Erarslan and Meral Şeker \\ Alanya Alaaddin Keykubat University, Faculty of Education, Antalya, Turkey
}

\begin{abstract}
Exploring higher education learners' e-learning experiences and the challenges they encounter is required to equip them with necessary skills and strategies to attain their academic goals (Cooper $\&$ Corpus, 2009). By identifying the types of and the frequency of exposure to distractors, the study was specifically geared towards finding out the level of motivational self-regulated strategies, including volition and goal commitment strategies, employed against online distractors during e-learning by higher education learners. The data were gathered through a questionnaire developed after a comprehensive literature review and semi-structured interviews $(n=38)$. The questionnaire was completed by higher education learners $(n=279)$, who were found to implement goal commitment and volition strategies at moderate levels despite the high frequency of exposure to distractors. The overall findings imply that equipping learners with motivational e-learning strategies encompassing goal commitment and volition strategies is necessary. This will require more in-depth research conducted to explore the role of self-regulated strategies in predicting learner engagement in the context of online learning.
\end{abstract}

Keywords: higher education, e-learning, self-regulated learning strategies, motivational strategies, online distractors

Erarslan, A., \& Şeker, M. (2021). Investigating e-learning motivational strategies of higher education learners against online distractors. Online Learning, 25(2), 262-279. https://doi.org/10.24059/olj.v25i2.2252

\section{Investigating E-Learning Motivational Strategies of Higher Education Learners against Online Distractors}

The spread of computers together with the use of the internet in learning environments has changed the way knowledge is constructed. This new way of learning with information and/or communication technologies have brought new terms into the field of learning and teaching such as technology-based learning, web-based learning, mobile learning, or online learning (Blake, 2011; Godwin-Jones, 2017; Gluchmanova, 2015; Guan, 2014; Klimova \& Polakova, 2020). More recently, "e-learning" has been the main term used to encompass all forms of learning facilitated through online technologies. Zhang et al. (2004) define "e-learning" as "technology-based learning 
in which learning materials are delivered electronically to remote learners via a computer network" (p. 76). The term "e-learning" used in the present study, on the other hand, is defined as "...electronically mediated asynchronous and synchronous communication for the purpose of constructing and confirming knowledge. The technological foundation of e-learning is the internet and associated communication technologies" (Garrison, 2011, p. 2).

Initially, e-learning was considered to be a new component of traditional education where teachers and learners benefitted from online resources to enhance formal education; however, over time, it has replaced the functions of traditional face-to-face education through distance learning programs (Watson, 2008). Today, educators who make use of web technologies in learning refer to such lessons in a number of forms such as a "web-facilitated class," a "blended" or "hybrid course," or a "fully virtual" or "online course" (Blake, 2011, p. 11) or more recently "massive open online course (MOOC)" (Xing, 2019). In fact, Web 2.0 technologies have allowed users to generate content through platforms such as blogs, wikis, or forums (Tiryakioglu \& Erzurum, 2011). In addition, social media platforms such as Facebook, Instagram, and Twitter have recently brought new dimensions to learning where users have the opportunity to create and share content (Aydin, 2012; Manca \& Ranieri, 2016; McCarroll \& Curran, 2013; Taskiran, et al., 2018).

E-learning makes it possible for learners to reach abundant information and to learn at any time anywhere (Maeroff, 2003; Pittinsky, 2003). As there are various advantages for all stakeholders, namely learners, teachers, and educational institutions, the number of higher education institutions providing distance education and online courses has been booming. While more than $80 \%$ of the universities in the United States offer online courses (Parker, Lenhart, \& Moore, 2011), the rate of offering online courses for other countries can go up to $50 \%$ in Asia, Africa, and the Middle East (Qayyum \& Zawacki-Richter, 2019). The popularity of recent elearning programs stems from their interactive, repetitive, flexible, and customizable nature (Allen \& Seaman, 2006; Arkorful \& Abaidoo, 2015; Costley \& Lange, 2018; Darling-Hammond et al., 2019; Ku \& Chang, 2011; Lekawael, 2017; Slater \& Davies, 2020; Waschull, 2001). This form of learning has been reported to provide various benefits for the new generation such as expanding access to more learning materials and sources (Hill, 2002; Hofmann, 2002; Li, 2007; Means et al., 2009); providing more affordable education opportunities for the learners that enhance active engagement (Katz \& Yablon, 2002; Li, 2007); leading to higher achievement (Katz \& Yablon, 2002; Rourke, 2001; Schrum, 2000); and maximizing the learning opportunities among several web-based tools, computer programs, MOOCs, or social media applications and platforms such as Facebook, Twitter, and Instagram (Abney et al., 2018; Aydin, 2012; Chawinga, 2017; Faizi et al., 2013; Fox \& Bird, 2017; Wong et al., 2017; Xing, 2019).

With the Covid-19 pandemic, the most frequently appreciated benefit of online education has been that it does not require learners and teachers to be in the same physical atmosphere. As Shea (2020) rightfully states, online learning has dramatically become the sole platform for education in many regions of the world because of the ongoing pandemic from COVID-19. This unexpected and meteoric transfer to online platforms has emphasized the significance of online platforms for education, which seems to be going to make up the majority of higher education, at least for the near future.

However, educators warn against overlooking the challenges that e-learning poses (Manca, 2020; Zhang et al., 2019). For Njenga and Fourise (2008) "e-learning in higher education . . is being created, propagated and channeled ... without giving educators the time and opportunity to explore the dangers and rewards of e-learning on teaching and learning" (p. 1). Research findings 
also indicate that the quality of e-learning needs to be maintained based on empirical and objective evaluations of how much the instructional designs available pertain to educational approaches (Reyes-Fournier et al., 2020; Veletsianos \& Houlden, 2019; Xing, 2019); of the quality of the learning materials, and of interactional opportunities (Li, 2007; Kuh, 2003), and maybe most importantly, of how satisfactory the e-learning engagement levels of learners are (Broadbent \& Poon, 2015; Kuh, 2003; Serdyukov, 2017). As Muir et al. (2019) states, to increase and improve learner engagement in e-learning environments and to acquire desired educational outcomes, a close investigation of the factors affecting online engagement and providing methods and strategies to guide both educators and learners are needed. Despite the need and the importance of research on learner engagement in e-learning environments and the influencing factors, no study could be found conducted in Turkish context.

\section{Attention vs. Distraction in E-Learning Engagement}

Engaged learners are reported to have increased cognitive and metacognitive involvement in academic tasks, increased performance and productivity and higher achievement rates (Krause \& Coates, 2008; Kuh, 2009; Slater \& Davies, 2020). However, studies also state that establishing and maintaining academic engagement can be challenging (Reyes-Fournier, et al., 2020; Martin, Stamper, \& Flowers, 2020). One of the significant factors affecting learner engagement is "attention." In the context of e-learning, the abundance of online sources of information requires learners to be able to allocate their full attention to relevant stimuli and to ignore irrelevant ones. Such irrelevant stimuli are referred to as distractors (Forster \& Lavie, 2011). The use of the internet for learning purposes means being constantly exposed to online distractors in these learning environments. While online to complete a learning task, learners can experience distraction because of various entertaining or commercial distractors present on the internet. These could be chatting through social media, reading the news, checking sports scores or other areas of interest, playing online games, or receiving ads or email messages and so on (Lim, 2002; Thatcher et al., 2008; Wan \& Chiou, 2006). Studies reveal that distraction hinders performance by affecting concentration on task and leading to procrastination (Andrade, 2012; Dembo \& Eaton, 2000; Rozek et al., 2012). Thus, it becomes a challenge for learners to maintain their determination to achieve their learning goals and to keep engaged while navigating among "abundant online learning resources" (Bonk et al., 2015).

Zhang et al. (2019) explored the over-abundancy of information sources available in online learning environments referring to it as "openness." Exploring the connections between the learning resources and the perceived knowledge patterns of the learners, they provided an atlas of online learning space. Their results indicated significant correlations between the learners' attention flow networks and their course scores. They have found that as the participant learners escalated their concentration on the task at hand, their scores increased. Pointing out to the importance of attention flow in academic achievement, they suggest that educational research need to focus more on exploring e-learning environments and learning behaviors in order to equip learners with necessary skills and strategies to enable them maximize their engagement and success. As one of the inhibitors of learners' attention, distractors in e-learning environments need serious consideration by educators in order to equip learners with specific strategies against these distractors to be committed to their learning goals (Gay \& Betts, 2020; Renn, 2003). At this point, investigating the role of self-regulated learning (SRL), which refers to the ability to plan, control, manage, and evaluate learning process (Zimmerman, 2008), could uncover the subtle predictors of learning engagement and success in e-learning contexts. 


\section{The Role of Strategy Use in E-Learning}

From the learner's perspective, the quality and the outcomes of e-learning experiences will more likely depend on the learner-related features such as their learning styles, skills, and strategies exerted during learning processes. Among the skills and the strategies learners employ, selfregulated learning (SRL) strategies have been reported to be strong predictors of academic engagement levels and success (Broadbent \& Poon, 2015; Oxford, 2011; Putri, 2020; Teng, Yuan, \& Sun, 2020; Wang et al., 2013).

SRL is defined as "an active, constructive process whereby learners set goals for their learning and then attempt to monitor, regulate, and control their cognition, motivation, and behaviour, guided and constrained by their goals and the contextual features in the environment" (Wolters et al., 2003, p.2). SRL strategies are grouped under four main categories: cognitive, metacognitive, affective, and sociocultural learning strategies (Oxford, 2011; Paris et al., 2001; Ziegler et al., 2003). While cognitive strategies are related to cognitive processes such as elaboration, reasoning, or rehearsal, metacognitive strategies help planning, monitoring, and evaluating, as well as self-managing the learning process (Bown \& White, 2010; Oxford, 2011; Wang et al., 2009). Sociocultural strategies, on the other hand, deal with the sociocultural context of the learning environment (Winne, 2005). Affective strategies organize emotional and motivational requirements such as developing self-confidence and perseverance, activating and maintaining concentration for and during learning. These strategies are activated to create an optimum emotional state to increase productivity in learning while enabling to shield undesired or disruptive emotional states such as feeling unmotivated or discouraged.

Motivational strategies, considered to be under affective learning strategies (Oxford, 2011), regulate learners' willingness or volition to achieve their learning goals by controlling, manipulating, or maintaining motivation for active engagement (Dembo \& Eaton, 2000; Wolters \& Rosenthal, 2000). Studies focusing on motivational regulation strategies have identified several sub-strategies that control volition. These emerging sub-strategies are categorized under concretebehavioral and mental-abstract strategies. Behavioral strategies involve actions such as organizing the study environment, taking precautions against distractors, or setting deadlines or rewards for task completion (Dembo \& Eaton, 2000; Duckworth et. al., 2016; Wolters \& Rosenthal, 2000). Mental or abstract volition strategies, on the other hand, refer to the mental processes triggered to enhance interest in the task that may involve efforts to make a task more relevant, enjoyable, or achievable (Wolters, 2003). When learners are able to regulate their volition strategies, they can enhance their engagement, maintain concentration to achieve their learning goals and can use strategies against online distractors. At this point, goal commitment, as one of the central constructs correlated with performance, refers to the degree of determination and persistence in achieving a goal (Locke et al., 1988; Renn, 2003). Optimum levels of goal commitment are shown to have an effect on cognitive task engagement by influencing the way information is processed, the strategies applied, and the implementation procedures carried out in a learning situation (Kanfer, 1990; Locke et al., 1988). Research also shows that being able to use learning strategies and having strong concentration increases levels of commitment and willingness to spend effort for learning while strengthening resistance to distractors (Darling-Hammond et al., 2019; Renn, 2003; Wofford et al., 1992). 


\section{Research Questions}

It is clear that further research needs to explore learners' e-learning experiences and the challenges they encounter so as to determine the strategies they need. However, hardly any research conducted so far has explored the role of distractors in online learning and the related literature is not sufficient to guide researchers and educators on effective methods and teaching practices to help learners deal with such distractors. The present study aims to develop a standard tool to explore e-learning behaviors of learners and thus, pioneer research focusing on online distractors and the strategies to overcome such challenges. The specific research questions sought for are:

(a) What are the means used for and the frequency of e-learning for higher education learners?

(b) What are the types of and the frequency of exposure to distractors during e-learning?

(c) In what levels do higher education learners employ strategies against distractors during elearning?

(d) Are there any significant differences among learners regarding the distractors being exposed to and the strategies employed against based on gender variable?

\section{Methods}

The study was mainly geared towards developing a practical tool to explore higher education learners' strategy use against distractors. The study was descriptive (Kampen \& Tamas, 2014) and designed to identify the distractors encountered in e-learning and the strategies learners employed against them. By developing a standard questionnaire, it is aimed to strengthen the reliability of the present study's findings by including contextual factors and to generate a valid tool for future research in similar contexts.

\section{Sample}

The participants were higher education students in education, business, and engineering departments of Turkish state universities: Alanya Alaaddin Keykubat University, Cukurova University, Pamukkale University, Kocaeli University, Gazi University, Hacettepe University. The sampling was conducted following convenience sampling method (Dörnyei, 2007). The inclusion criteria consisted of easy accessibility, availability at the time of data collection, and willingness to participate. Therefore, written consent forms from the participants were received and the researchers' institution was informed about the possible ethical concerns during our research before initiating the research. As a result, two sample groups were formed. The first group of learners $(n=38)$ were interviewed previous to the development of the scale. This group served the purpose of acquiring situational insights into e-learning habits of higher education learners in Turkish universities. While the extensive review of literature conducted prior to developing the questionnaire for the study provided theoretical and practical insights from various settings around the world, the data gathered from the semi-structured interviews with this sample of Turkish higher education learners enabled the researchers to obtain information on learners' e-learning habits and experiences from the Turkish perspective. This group included 21 female and 17 male learners aged between 18 and 22 .

The second sample consisted of 279 higher education learners in total and were asked to complete the questionnaire following the development of the scale. Both sample groups were 
previously informed about the research and were invited to participate if they were willing. The learners who signed a consent form were included in the samples. Table 1 displays demographic information of the participant learners that completed the questionnaire.

\section{Table 1}

Demographic Information of the Participants Completing the Questionnaire

\begin{tabular}{llllllllll}
\hline \multicolumn{3}{c}{ Gender } & \multicolumn{3}{c}{ Age (years) } & \multicolumn{3}{c}{ Faculty } \\
\hline \multirow{3}{*}{$F$} & Female & Male & $16-18$ & $19-21$ & $22-24$ & $25+$ & Engineering & Education & Business \\
\cline { 2 - 10 }$\%$ & 119 & 160 & 59 & 165 & 33 & 22 & 151 & 91 & 37 \\
\hline
\end{tabular}

The sample included 160 (57.3\%) male participants while female participants formed $42.6 \%$ of the study group. The participants mostly were aged between 19 and $21(59.1 \%)$ followed by $16-18$ years old $(21.1 \%)$. The participants from engineering faculty constituted more than half of the participants $(54.1 \%)$ followed by education $(32.6 \%)$ and business $(13.2 \%)$ faculties.

\section{Development of Instruments}

The questionnaire was developed following several steps. The first step was an extensive review of relevant literature. Research conducted between 2000 and 2019 were determined using keywords such as "online study habits," online distractors," "online learning in higher education," and "learner strategies for online learning". The collected studies were read carefully in order to identify the general issues and/or categories mentioned in these studies. These were noted and the themes repeated in more than one study were determined to be included in the interviews. Accordingly, the research compiled yielded the following categories: (a) e-learning habits and frequency, (b) distraction during e-learning, and (c) strategies used against online distractors.

The second step involved constructing the interview questions. Based on the identified categories in the review of relevant research, seven open-ended questions were prepared in a semistructured interview design. The questions were directed toward: (a) e-learning habits and frequency, (b) devices used for e-learning, (c) frequency of being exposed to online distractors and their types, and (d) strategies used against such distractors (see Appendix 1). Afterwards, the interviews were conducted with 38 students with the presence of the two researchers and were recorded.

The final step of item development of the questionnaire involved comparing the themes and the dimensions gathered from the literature review and the learner interviews. The common themes were included under the relevant categories defined in the review of relevant research. The themes that were confusing or that seemed too abstract or irrelevant were excluded from the questionnaire. After the items and the dimensions were defined, the accuracy and the clarity of the items were revised first by the two researchers separately. Upon the modifications made, two other academicians working at the same university revised the questionnaire: one was an expert in statistics and the other was an expert in research design. Completing the four revisions and the alterations suggested, the questionnaire at this stage had two parts. The first part included six questions related to learners' demographic information such as age, gender, majoring field, and online study habits like the frequency and the tools used for online studying. The second part 
included 39 items grouped under two dimensions: (a) online distractors and (b) strategies applied against distractors. The items were designed in a five-point Likert Scale format, anchored by "always" (1), "often" (2), "sometimes" (3), "rarely" (4), and "never" (5).

As the next step of the data analysis, EFA was conducted in order to identify the factors and to reduce the data for further analyses. EFA enables to determine associations among variables by reducing the data for each dimension and determining the number of factors (Pallant, 2001).

Kaiser-Meyer-Olkin (KMO) Test and Bartlett's Test showed that the data set was suitable for factor analysis revealing high correlation among the variables $(\mathrm{KMO}=0.837$; Bartlett's $\mathrm{df}=$ $253 ; \mathrm{p}=0.00<0.05$ ). As the next step of the analysis, Initial Eigenvalue analysis was calculated to identify the significant factors. The irrelevant, confusing or weak items (with less than .30 item correlation or the ones that were loaded under more than one factor at high levels) were eliminated from the questionnaire one by one and the test was repeated (Kalayci, 2010; Pallant, 2001). As a result of these calculations, the final version of the questionnaire revealed 23 items loading significantly (greater than 1 eigenvalue) under four factors: (a) Goal Commitment, (b) Mental Volition Strategies, (c) Distractors, and (d) Behavioural Volition Strategies. The items in these factors comprised $53.22 \%$ of the total variance explained. The Scree Test of Eigenvalues confirmed the same number of factors $(n=4)$ to have values greater than 1 . In order to list the items under the factor in which they correlate the highest, Quartimax with Kaiser Normalization method was used to rotate the data and to form the items in groups to constitute different factors (Field, 2005; Pallant, 2001). The factors with the items and their loadings are displayed in Table 2.

\section{Table 2}

Quartimax Rotation Test Scores and Factor Loadings of Items

\begin{tabular}{|c|c|c|c|c|}
\hline & Factor 1 & Factor 2 & Factor 3 & Factor 4 \\
\hline \multicolumn{5}{|l|}{ Total Variance Explained $53.22 \%$} \\
\hline Item 28: I prepare a study plan before starting to study & .802 & & & \\
\hline Item 17: I apply the study plan I prepare & .768 & & & \\
\hline $\begin{array}{l}\text { Item 38: I plan how to complete the tasks before starting } \\
\text { to study }\end{array}$ & .639 & & & \\
\hline Item 39: I make sure I follow my study plan & .625 & & & \\
\hline Item 7: I set time for myself for studying & .592 & & & \\
\hline Item 19: I set challenging goals before starting to study & .511 & & & \\
\hline $\begin{array}{l}\text { Item 35: I think about finding precautions against online } \\
\text { distractors }\end{array}$ & & 697 & & \\
\hline $\begin{array}{l}\text { Item 6: I promise myself not to finish studying before } \\
\text { attaining my goals }\end{array}$ & & .696 & & \\
\hline Item 12: I have high self-control not to get distracted & & 673 & & \\
\hline Item 31: I remind myself to stick to my study plan & & .599 & & \\
\hline Item 10: I think of strategies to concentrate on my goals & & .571 & & \\
\hline Item 37: I promise to leave my mobile away from me & & .484 & & \\
\hline Item 16: I check my social media accounts & & & .719 & \\
\hline Item 32: I get phone calls & & & 690 & \\
\hline $\begin{array}{l}\text { Item 22: I get message notifications (e.g. Instagram, } \\
\text { Facebook, WhatsApp) }\end{array}$ & & & .687 & \\
\hline
\end{tabular}




\begin{tabular}{lll}
\hline Item 33: I check my emails & .628 & \\
Item 23: I watch videos (e.g. YouTube) & .555 & \\
Item 15: I answer the messages and continue to study & .492 & \\
Item 4: I surf on other webpages & .475 & .772 \\
Item 27: I set my phone to "do not disturb" or silent mode & & .762 \\
Item 34: I mute notifications & .552 \\
Item 8: I block all notifications & .384 \\
Item 24 I close irrelevant apps & & .38 \\
\hline
\end{tabular}

The results show that the first factor loading with highest values (Goal Commitment) had six items (items $7,17,19,28,38,39$ ) and explained $23.77 \%$ of the total variance. Factor 2 (Mental Volition Strategies) explained $12.31 \%$ of the total variance with six items loading significantly (items 6, 10, 12, 31, 35, 37). Another seven items loaded the highest under the third factor (Distractors) explaining $10.20 \%$ of the total variance (items $4,15,16,22,23,32,33$ ) while the fourth factor (Behavioural Volition Strategies) had four items that loaded the highest (items 8, 24, $27,34)$ and explained $6.69 \%$ of the total variance. The questionnaire's overall reliability was recalculated with the 23 items left. Cronbach's Alpha Coefficient test showed that the questionnaire was reliable $(\alpha=$.773) (Pallant, 2001).

The factors and the items in the final version of the questionnaire, and the descriptive results for each component are presented in Table 3. Regarding the results for the reliability analyses for each emerging factor, it was found that each dimension of the questionnaire was statistically reliable for further analysis.

\section{Table 3}

Descriptive and Reliability Estimates for e-Learning Behaviors Questionnaire

\begin{tabular}{|c|c|c|c|c|c|c|c|c|c|}
\hline \multirow[t]{2}{*}{ Factors } & \multirow[t]{2}{*}{ Items } & \multicolumn{5}{|c|}{ Responses (\%) } & \multirow[t]{2}{*}{ Mean } & \multirow[t]{2}{*}{ Sd } & \multirow[t]{2}{*}{$\alpha$} \\
\hline & & Always & Often & Sometimes & Rarely & Never & & & \\
\hline \multirow{6}{*}{$\begin{array}{l}\text { Goal } \\
\text { Commitment } \\
\text { strategies } \\
\text { (6 items) }\end{array}$} & I set time for myself for studying & 10.1 & 24.6 & 30.6 & 25.4 & 9.3 & \multirow{6}{*}{2.88} & \multirow{6}{*}{.772} & \multirow{6}{*}{.807} \\
\hline & I apply the study plan I prepare & 10.1 & 21.8 & 35.9 & 25.4 & 6.9 & & & \\
\hline & $\begin{array}{l}\text { I set challenging goals before } \\
\text { starting to study }\end{array}$ & 11.7 & 20.2 & 38.3 & 23.8 & 6.0 & & & \\
\hline & $\begin{array}{l}\text { I prepare a study plan before } \\
\text { starting to study }\end{array}$ & 14.5 & 22.6 & 35.5 & 21.8 & 5.6 & & & \\
\hline & $\begin{array}{l}\text { I plan how to complete the tasks } \\
\text { before starting to study }\end{array}$ & 13.7 & 26.6 & 36.7 & 18.1 & 4.8 & & & \\
\hline & I make sure I follow my study plan & 10.9 & 25.0 & 38.7 & 19.4 & 6.0 & & & \\
\hline \multirow{6}{*}{$\begin{array}{l}\text { Mental } \\
\text { Volition } \\
\text { Strategies } \\
\text { (6 items) }\end{array}$} & $\begin{array}{l}\text { I remind myself to stick to my study } \\
\text { plan }\end{array}$ & 3.2 & 16.9 & 37.9 & 31.0 & 10.9 & \multirow{6}{*}{3.15} & \multirow{6}{*}{.682} & \multirow{6}{*}{.750} \\
\hline & $\begin{array}{l}\text { I think about finding precautions } \\
\text { against online distractors }\end{array}$ & 6.0 & 12.5 & 49.2 & 23.8 & 8.5 & & & \\
\hline & $\begin{array}{l}\text { I have high self-control not to get } \\
\text { distracted }\end{array}$ & 8.5 & 19.0 & 39.9 & 20.2 & 12.5 & & & \\
\hline & $\begin{array}{l}\text { I think of strategies to concentrate } \\
\text { on my goals }\end{array}$ & 10.1 & 43.5 & 26.2 & 16.1 & 4.0 & & & \\
\hline & $\begin{array}{l}\text { I promise myself not to finish } \\
\text { studying before attaining my goals }\end{array}$ & 8.9 & 15.7 & 48.0 & 20.6 & 6.9 & & & \\
\hline & $\begin{array}{l}\text { I promise to leave my mobile away } \\
\text { from me }\end{array}$ & 4.8 & 10.5 & 30.6 & 29.0 & 25.0 & & & \\
\hline
\end{tabular}




\begin{tabular}{|c|c|c|c|c|c|c|c|c|c|}
\hline Factors & Items & & & esponses $(\%$ & & & Mean & Sd & $\alpha$ \\
\hline \multirow{8}{*}{$\begin{array}{l}\text { Distractors } \\
\text { ( } 7 \text { items) }\end{array}$} & & Always & Often & Sometimes & Rarely & Never & \multirow{8}{*}{2.63} & \multirow{8}{*}{.669} & \multirow{8}{*}{.741} \\
\hline & I surf on other webpages & 16.1 & 37.5 & 33.5 & 10.9 & 2.0 & & & \\
\hline & $\begin{array}{l}\text { I answer the messages and continue } \\
\text { to study }\end{array}$ & 11.3 & 33.1 & 37.9 & 14.1 & 3.6 & & & \\
\hline & $\begin{array}{l}\text { I get message notifications (e.g. } \\
\text { Instagram, Facebook, WhatsApp) }\end{array}$ & 28.6 & 36.7 & 21.0 & 9.7 & 4.0 & & & \\
\hline & I watch videos (e.g. YouTube) & 32.3 & 37.9 & 18.1 & 7.7 & 4.0 & & & \\
\hline & I get phone calls & 14.9 & 15.7 & 44.0 & 20.6 & 4.8 & & & \\
\hline & I check my emails & 7.7 & 11.3 & 27.0 & 29.8 & 24.2 & & & \\
\hline & I check my social media accounts & 18.1 & 31.5 & 29.4 & 15.7 & 5.2 & & & \\
\hline \multirow{4}{*}{$\begin{array}{l}\text { Behavioural } \\
\text { Volition } \\
\text { Strategies } \\
\text { (4 items) }\end{array}$} & I block all notifications & 7.7 & 7.7 & 34.7 & 33.1 & 16.9 & \multirow{4}{*}{3.15} & \multirow{4}{*}{.812} & \multirow{4}{*}{.689} \\
\hline & $\begin{array}{l}\text { I set my phone to "do not disturb" } \\
\text { or silent mode }\end{array}$ & 10.9 & 23.8 & 31.0 & 21.0 & 13.3 & & & \\
\hline & I close irrelevant apps & 9.7 & 15.3 & 37.9 & 25.4 & 11.7 & & & \\
\hline & I mute notifications & 11.7 & 18.1 & 36.7 & 22.6 & 10.9 & & & \\
\hline
\end{tabular}

\section{Data Analysis}

Two separate sets of data were used for the study. The first set included qualitative data gathered from the review of literature and the semi-structured interviews with the first sample group. The data obtained from the review of literature was analyzed using content analysis (Krippendorff, 2018), where the documents were systematically analyzed to identify repeated issues and critical points in online learning process. As a result, the main categories were determined to guide the development of the semi-structured interview questions and the questionnaire. As for the qualitative data obtained from the learners' interviews, first, the recorded data were transcribed verbatim. Then, systematic content analysis was conducted by the two researchers separately to identify the emerging themes under each category defined as a result of reviewed research. The inter-coder reliability was measured using Cohen's kappa to identify the degree of agreement between the themes elicited by the two researchers and was found to have high reliability (.84) (Cohen, 1968).

The data from the questionnaires was manually transferred to a computer environment and analyzed using Statistical Package for Social Sciences (SPSS) 17.0. The response rate was 100\% with no missing data. First, the data regarding the frequency of e-learning and the device used for access was analyzed descriptively. Then, the second part that consisted of 39 items under two dimensions were analyzed using Explanatory Factor Analysis (EFA) and the relevant reliability and validity tests were conducted. The first step of the statistical analyses involved descriptive values. The descriptive values of the initial 39 items were $\mathrm{M}=2.97$ and $\mathrm{SD}=.812$. The internal reliability of the questionnaire was measured using Cronbach's Alpha Coefficient (Cronbach, $1951)$ and it was found that the data set was suitable to conduct further statistical tests $(\alpha=.801)$. The quantitative data gathered from the questionnaires, on the other hand, was analyzed statistically using descriptive statistics, i.e., mean values and frequencies were calculated to determine the learners' e-learning habits, while an independent samples t-test was run to investigate possible differences among the participants' responses. 


\section{Results}

\section{Frequency of E-Learning and the Devices Used}

Table 4 displays the descriptive analyses results for the participant learners' frequency of e-learning and the devices they use.

\section{Table 4}

The Frequency of e-Learning and the Devices Used

\begin{tabular}{|c|c|c|c|c|c|c|c|c|}
\hline & \multicolumn{3}{|c|}{ Frequency of Studying Online } & \multicolumn{5}{|c|}{ Device used to Study Online } \\
\hline & $\begin{array}{l}\text { Few times a } \\
\text { month }\end{array}$ & $\begin{array}{l}\text { Few times } \\
\text { a week }\end{array}$ & $\begin{array}{l}\text { Several times a } \\
\text { week }\end{array}$ & Everyday & Mobile & Tablet & $\begin{array}{l}\text { Laptop } \\
\text { Computer }\end{array}$ & $\begin{array}{l}\text { Desktop } \\
\text { Computer }\end{array}$ \\
\hline $\mathbf{F}$ & 107 & 109 & 42 & 21 & 224 & 5 & 46 & 3 \\
\hline$\%$ & 38.3 & 39.0 & 15.0 & 7.5 & 80.2 & 1.7 & 16.4 & 1.0 \\
\hline
\end{tabular}

According to the results, the participants did not study online very frequently. Rather, most of them studied online a few times a month $(38.3 \%)$ or a few times a week $(39.0 \%)$. For the device used, a significant majority reported that they used their mobile phones $(80.2 \%)$. While some of them were using laptop computers to study online $(16.4 \%)$, only very few used tablets $(1.7 \%)$ or desktop computers $(1.0 \%)$.

\section{Exposure to Online Distractors and the Use of Strategies}

The data were analyzed descriptively after the results of the factor analyses were attained to find out the participants' tendencies for each dimension. As for the participants' exposure to distractors, the mean score $(\mathrm{M}=2.6)$ indicates that it was at moderate levels as the value is higher than 2, referring to being exposed to distractors often (represented by 2) or sometimes (represented by 3). The distractor with the highest frequency was reported to be watching videos while studying online $(32.3 \%$ always and $37.9 \%$ often), followed by getting notifications from social media accounts (28.6\% always and $36.7 \%$ often), and surfing on other webpages $(37.5 \%$ often and $33.5 \%$ sometimes) while getting phone calls (44.0\% sometimes) was also stated as another frequent distractor. As for the goal commitment strategies, the participants seemed to apply them less frequently $(\mathrm{M}=2.8)$. The most frequent ones they employed were setting challenging goals $(38.3 \%$ sometimes), preparing and applying a study plan (35.5\% and 35.9\% sometimes, respectively), and making sure that they follow the plan prepared (38.7\% sometimes). The responses for planning how to complete the tasks ( $26.6 \%$ often and $36.7 \%$ sometimes) and setting time for them $(24.6 \%$ often and $30.6 \%$ sometimes) were also at moderate levels. Only a few students (between 10-14\%) reported to always use these goal commitment strategies.

The results for mental and behavioral volition strategies $(M=3.15)$ indicate that the participants applied these strategies less than goal commitment strategies. Very few participants (between $6.0 \%$ and $16.1 \%$ ) always used mental volition strategies. They mostly used thinking about concentration strategies ( $43.5 \%$ often) followed by thinking about finding precautions (49.2\% sometimes), promising themselves not to stop studying before the goals are attained (48.0\% sometimes), having high self-control (39.9\% sometimes), and reminding themselves to stick to their study plans $(23.8 \%$ often and $31.0 \%$ sometimes). However, a considerable number of the participants (between 10.9\% and 29.0\%) also stated that they use these strategies rarely, which may suggest that the majority of the students do not very frequently apply these strategies. 
As for the behavioral volition strategies, the results do not imply high frequency of use by most of the participants, either. The most frequent response was setting mobile phones to "do not disturb" or silent modes (37.9\% sometimes), while closing apps (37.9\% sometimes), muting, or blocking notifications (36.7\% and $34.7 \%$ sometimes) were the moderately used behavioral volition strategies.

\section{Differences in the Use of Strategies Based on Gender}

The results of Independent Samples T-Test conducted to find out possible differences among the participants indicate that female and male learners $(\mathrm{M}=2.55$ and $\mathrm{M}=2.67$, respectively) did not differ significantly in the frequency of being exposed to distractors $(\mathrm{t}=-1.40$. $\mathrm{df}=246 . \mathrm{p}=.162>.05)$.

In terms of the strategies applied against online distractors, no statistically significant differences were found for behavioral volition strategies $(t=-1.58 . \mathrm{df}=246 . \mathrm{p}=.115>.05)$ and for mental volition strategies $(\mathrm{t}=.68 \mathrm{df}=246 . \mathrm{p}=.571>.05)$. However, gender played a significant role in terms of using goal commitment strategies $(t=-4.88 . \mathrm{df}=246 . \mathrm{p}=.00>.05)$. The effect size of this difference calculated using eta square value also confirms the effect of gender on the frequency of goal commitment strategy use $(\eta 2=.21>.14)$ (Huck, 2008). Accordingly, the effect size is greater for female learners, who were found to be using goal commitment strategies more frequently than male learners do $(\mathrm{M}=3.34$ and $\mathrm{M}=2.58$, respectively).

Overall, the results show that almost half of the participants used goal commitment and mental and behavioral volition strategies rarely/never although a significant number of the participants stated they were always/often exposed to distractors while studying online.

\section{Discussion}

The dramatic in the use of the internet for learning require educators and educational program developers not only to plan and prepare efficient online learning tools but also to monitor the efficiency of learners' e-learning experiences and to be able to optimize learning outcomes. Yet, further research, particularly based on Turkish learners, exploring e-learner behaviors and the obstacles they need to cope with is still needed. The present study attempted to lead to further research by reporting the development of and introducing the questionnaire to investigate higher education learners' e-learning behaviors focusing specifically on online distractors being exposed to and the strategies applied to keep committed to their learning goals within Turkish higher education.

The results reveal that higher education learners study online at moderate levels, i.e., a few times a month or a week using mostly their mobile phones, though there are some who do more frequently. Regarding the frequency of being exposed to distractors, the participants reported exposure at high to moderate rates. However, when it comes to the implementation of strategies against such distractors, the results indicate low to moderate levels of use of such strategies. Still, goal commitment strategies were reported to be performed more frequently than behavioral and mental volition strategies among learners. On the other hand, the female learners were found to use goal commitment strategies significantly higher than their male peers.

As Mehlenbacher et al. (2000) warn educators, studying online needs closer examination and evaluation. Attempts to optimize e-learning behaviors of learners will require first to explore their learning engagement, the impacts of e-learning on learner performance and achievement. 
Having a clearer picture of learner experiences can guide educators to develop and/or adapt teaching and learning strategies that would assist learners when studying online. The internet provides not only learning tools but also a wide variety of distractors. Learners are expected to keep their concentration on task despite such obstacles and avoid cyber slacking (Lavoie \& Pychyl, 2001). Therefore, equipping learners to set goals and to regulate volition strategies could be regarded among the necessary skills for future generations. Control over the task and regulating strategies for achieving academic goals are considered to be among the important components of learning flow (Zimmerman, 1989), which is defined as a conscious state of deep engagement in a learning task at hand (Chen, 2006; Thatcher et al., 2008). When learners are able to regulate their own learning, the likelihood of achieving their goals increases (Achtziger et al., 2008). Nonetheless, as Cooper and Corpus (2009) argue, research on SRL strategies mostly focuses on cognitive and metacognitive strategies leaving motivational strategies investigated to a lesser extent. However, with the increase in online learning, learners need to regulate their motivational strategies in order to maintain their engagement and to cope with distractors. Today almost all higher education students, whether enrolled in online programs or traditional face-to-face programs, use the internet for learning. In order to be efficient e-autonomous learners, they need to be equipped specifically with self-control encompassing goal commitment and volition strategies along with cognitive and metacognitive strategies of SRL.

\section{Conclusion}

The present study aims to contribute to the educational research investigating the role of strategy implementation in e-learning contexts, which has become more important than ever during the COVID-19 pandemic period (Shea, 2020; Johnson, Veletsianos \& Seaman, 2020). By developing a questionnaire to identify the use of volition and goal commitment strategies against online distractors, the results are meant to encourage further research. As SRL strategy implementation has been frequently reported to help learners to increase their academic engagement (Andrade \& Bunker, 2009; Oxford, 2011) and to obtain higher levels of achievement (Beishuizen \& Steffens, 2011; Zimmerman \& Schunk, 2008) in face-to-face learning environments, there is a need for more research to find out whether learners can benefit from using SRL strategies in online learning contexts. As the scope of this study is limited to the implementation of volition and goal commitment strategies against online distractors, future research could focus on other domains of SRL and their role in learner engagement and success. The results of the study also indicate that e-learning experiences of higher education learners call for further in-depth examination in order to identify psychometric qualities of motivational strategies and provide insights to the scientific community so that necessary actions could be sought by educators, program developers, and learners. 


\section{References}

Abney, A. K., Cook, L. A., Fox, A. K., \& Stevens, J. (2019). Intercollegiate social media education ecosystem. Journal of Marketing Education, 41(3), 254-269. https://doi.org/10.1177/0273475318786026

Achtziger, A., Gollwitzer, P. M., \& Sheeran, P. (2008). Implementation intentions and shielding goal striving from unwanted thoughts and feelings. Personality and Social Psychology Bulletin, 34(3), 381-393.

Allen, I. \& Seaman, J. (2006). Growing by degrees: Online education in the United States, 2005. The Sloan Consortium.

Andrade, M. S. (2012). Self-regulated learning activities: Supporting success in online courses. In J. L. Moore (Ed.), International perspectives of distance learning in higher education (pp. 111132). InTech.

Andrade, M. S., \& Bunker, E. L. (2009). A model for self-regulated distance language learning. Distance Education, 30, 47-61.

Arkorful, V., \& Abaidoo, N. (2015). The role of e-learning, advantages and disadvantages of its adoption in higher education. International Journal of Instructional Technology and Distance Learning, 12(1), 29-42.

Aydin, S. (2012). A review of research on Facebook as an educational environment. Educational Technology Research and Development, 60(6), 1093-1106. https://doi.org/10.1007/s11423012-9260-7

Beishuizen, J., \& Steffens, K. (2011). A conceptual framework for research on self-regulated learning. In R. Carneiro, P. Lefrere, K. Steffens, \& J. Underwood (Eds.), Self-regulated learning in technology enhanced learning environments: A European perspective (pp. 3-19). Sense Publishers.

Blake, R. J. (2011). Current trends in online language learning. Annual Review of Applied Linguistics, 31, 19-35.

Bonk, C. J., Lee, M. M., Reeves, T. C., \& Reynolds, T. H. (2015). MOOCs and open education around the world. Routledge.

Bown, J., \& White, C. J. (2010). Affect in a self-regulatory framework for language learning. System, $38,432-443$.

Broadbent, J., \& Poon, W. L. (2015). Self-regulated learning strategies \& academic achievement in online higher education learning environments: A systematic review. The Internet and Higher Education, 27, 1-13.

Chawinga, W. D. (2017). Taking social media to a university classroom: Teaching and learning using Twitter and blogs. International Journal of Educational Technology in Higher Education, 14(3), 1-19. https://doi:10.1186/s41239-017-0041-6

Chen, H. (2006). Flow on the net-Detecting Web users' positive effects and their flow states. Computers in Human Behavior, 22, 221-233.

Cohen, J. (1968). Weighted Kappa: Nominal scale agreement provision for scaled disagreement or partial credit. Psychological Bulletin, 70(4), 213-220. https://doi.org/10.1037/h0026256 
Cooper, C. A., \& Corpus, J. H. (2009). Learners' developing knowledge of strategies for regulating motivation. Journal of Applied Developmental Psychology, 30(4), 525-536.

Costley, J., \& Lange, C. (2018). The moderating effects of group work on the relationship between motivation and cognitive load. The International Review of Research in Open and Distributed Learning, 19(1), 68-90.

Cronbach, L. J. (1951). Coefficient alpha and the internal structure of tests. Psychometrika, 16(3), 297-334.

Darling-Hammond, L., Flook, L., Cook-Harvey, C., Barron, B., \& Osher, D. (2019). Implications for educational practice of the science of learning and development. Applied Developmental Science, 1-44. https://doi.org/10.1080/10888691.2018.1537791

Dembo, M. H., \& Eaton, M. J. (2000). Self-regulation of academic learning in middle-level schools. The Elementary School Journal, 100, 473-490.

Dörnyei, Z. (2007). Research methods in applied linguistics. Oxford University Press.

Duckworth. A. L., White. R. E., Matteucci. A. J., Shearer. A., \& Gross. J. J. (2016). A stitch in time: Strategic self-control in high school and college students. Journal of Educational Psychology, 108(3), 329-341.

Faizi, R., Afia, A. El, \& Chiheb, R. (2013). Exploring the potential benefits of using social media in education. International Journal of Emerging Technologies in Learning, 3(4), 50-53.

Field, A. (2005). Discovering statistics using SPSS. Sage Publications.

Forster, S., \& Lavie, N. (2011). Entirely irrelevant distractors can capture and captivate attention. Psychonomic Bulletin \& Review, 18(6), 1064-1070.

Fox, A., \& Bird, T. (2017). Any use? What do we know about how teachers and doctors learn through social media use? Open and Interdisciplinary Journal of Technology, Culture and Education, 12(2), 64-87.

Garrison, D. R. (2011). E-learning in the 21st century: A framework for research and practice. Taylor \& Francis.

Gay, G. H., \& Betts, K. (2020). From discussion forums to eMeetings: Integrating high touch strategies to increase student engagement, academic performance, and retention in large online courses. Online Learning, 24(1), 92-117.

Gluchmanova, M. (2015). Application of e-learning in foreign language teaching at the technical university. Procedia-Social and Behavioral Sciences, 174, 3144-3149.

Godwin-Jones, R. (2017). Smartphones and language learning. Language Learning \& Technology, 21(2), 3-17.

Guan, S. (2014). Internet-based technology use in second language learning: A systematic review. International Journal of Cyber Behavior, Psychology and Learning (IJCBPL), 4(4), 69-81.

Hill, J. R. (2002). Overcoming obstacles and creating connections: Community building in Webbased learning environments. Journal of Computing in Higher Education, 14(1), 67-86.

Hofmann, D. W. (2002). Internet-based distance learning in higher education. Tech Directions, 62(1), $28-32$. 
Johnson, N., Veletsianos, G., \& Seaman, J. (2020). U.S. faculty and administrators' experiences and approaches in the early weeks of the COVID-19 pandemic. Online Learning Journal, 24(2), 6 21.

Kalayc1, Ş. (2010). SPSS Uygulamalı Çok Değişkenli Istatistik Teknikleri [SPSS Multiple Variable Statistical Applications]. Asil Yayın Dağıtım.

Kampen, J. K., \& Tamás, P. (2014). Overly ambitious: Contributions and current status of Q methodology. Quality \& Quantity, 48(6), 3109-3126.

Kanfer, R. (1990). Motivation theory and industrial and organizational psychology. In M. Dunnette, \& L. Hough (Eds.), Handbook of Industrial and Organizational Psychology (pp. 75-170). Consulting Psychologists Press.

Katz, Y. J., \& Yablon, Y. B. (2002). Who is afraid of university internet courses? Educational Media International, 39(1), 69-73.

Klimova, B., \& Polakova, P. (2020). Students' perceptions of an EFL vocabulary learning mobile application. Education Sciences, 10(2), 1-8. https://doi.org/10.3390/educsci10020037

Krause, K. L., \& Coates, H. (2008). Students' engagement in first-year university. Assessment \& Evaluation in Higher Education, 33(5), 493-505.

Krippendorff, K. (2018). Content analysis: An introduction to its methodology. Sage Publications.

$\mathrm{Ku}, \mathrm{D} .$, \& Chang, C. (2011). The effect of academic discipline and gender difference on Taiwanese college students' learning styles and strategies in web-based learning environments. Turkish Online Journal of Educational Technology, 10(3), 265-272.

Kuh, G. D. (2003). What we're learning about student engagement from NSSE. Change, 35, 24-31.

Kuh, G. D. (2009). What student affairs professionals need to know about student engagement. Journal of College Student Development, 50(6), 683-706.

Lavoie, J., \& Pychyl, T. A. (2001). Cyber-slacking and the procrastination superhighway: A webbased survey of online procrastination, attitudes, and emotion. Social Science Computer Review, 19, 431-444.

Lekawael, R. F. J. (2017). The impact of smartphone and internet usage on English language learning. English Review: Journal of English Education, 5(2), 255-262.

Li, M.-H. (2007). Lessons learned from web-enhanced teaching in landscape architect studios. International Journal on E-Learning, 6(2), 2005-2008.

Lim, V. K. G. (2002). The IT way of loafing on the job: Cyberloafing, neutralizing, and organizational justice. Journal of Organizational Behavior, 23, 675-694.

Locke, E. A., Latham, G. P., \& Erez, M. (1988). The determinants of goal commitment. Academy of Management Review, 13, 23-39.

Maeroff, G. I. (2003). A classroom of one: How online learning is changing our schools and colleges. Palgrave MacMillan.

Manca, S. (2020). Snapping, pinning, liking or texting: Investigating social media in higher education beyond Facebook. The Internet and Higher Education. 44, 1-13. https://doi.org/10.1016/j.iheduc.2019.100707 
Manca S., \& Ranieri, M. (2016). Is Facebook still a suitable technology-enhanced learning environment? An updated critical review of the literature from 2012 to 2015. Journal of Computer Assisted Learning, 32(6), 503-528. https://doi.org.10.1111/jcal.12154

Reyes-Fournier, E., Cumella, E. J., Blackman, G., March, M. \& Pedersen, J. (2020). Development and validation of the online teaching effectiveness scale. Online Learning Journal, 24(2), 111127.

Martin, F., Stamper, B., \& Flowers, C. (2020). Examining student perception of readiness for online learning: Importance and confidence. Online Learning Journal, 24(2), 38-58.

McCarroll, N., \& Curran, K. (2013). Social networking in education. International Journal of Innovation in the Digital Economy, 4(1), 1-16. https://doi.org/10.4018/jide.2013010101

Means, B., Toyama, Y., Murphy, R., Bakia, M., \& Jones, K. (2009). Evaluation of evidence-based best practices in online learning: A meta-analysis and review of online learning studies. U.S. Department of Education.

Mehlenbacher, B., Miller, C. R., Covington, J. S., \& Larsen, J. S. (2000). Active and interactive learning online: a comparison of web-based and conventional writing classes. IEEE Transactions on Professional Communication, 43, 166-184.

Muir, T., Milthorpe, N., Stone, C., Dyment, J., Freeman, E., \& Hopwood, B. (2019). Chronicling engagement: Students' experience of online learning over time. Distance Education, 40(2), $262-277$.

Njenga, J. K., \& Fourise, L. C. H. (2008). The myths about e-learning in higher education. British Journal and Educational Technology, 39(7), 1-14.

Oxford, R. L. (2011). Teaching and researching language learning strategies. Pearson Longman.

Pallant, J. (2001). SPSS survival manual. Open University Press.

Paris, S. G., Byrnes, J. P., \& Paris, A. H. (2001). Constructing theories, identities, and actions of selfregulated learners. In B. J. Zimmerman \& D. H. Schunk (Eds.), Self-regulated learning and academic achievement: Theoretical perspectives (pp. 253-288). Lawrence Erlbaum.

Parker, K., Lenhart, A., \& Moore, K. (2011). The digital revolution and higher education: College presidents, public differ on value of online learning. Pew Internet \& American Life Project. http://files.eric.ed.gov/fulltext/ED524306.pdf

Pittinsky, M. S. (2003). The wired tower: Perspectives on the impact of the internet on higher education. Pearson Education.

Putri, V. A. (2020). The English-learning strategies of an indigenous English learner in the northeast of Thailand. Indonesian EFL Journal, 6(1), 11-18. doi: 10.25134/ieflj.v6i1.2633

Qayyum A., Zawacki-Richter O. (2019) The state of open and distance education. In O. ZawackiRichter, A. Qayyum (Eds), Open and distance education in Asia, Africa and the Middle East (pp. 125-140). Springer.

Renn, R. W. (2003). Moderation by goal commitment of the feedback-performance relationship: Theoretical explanation and preliminary study. Human Resource Management Review, 13(4), 561-580.

Rourke, J. R. (2001). Online learning: Fad or fate? Principal Leadership, 1(9), 8-14. 
Rozek, E., Kemper, S., \& McDowd, J. (2012). Learning to ignore distracters. Psychology and Aging, 27, 61-66. https://doi.org10.1037/a0025578

Serdyukov, P. (2017). Innovation in education: what works, what doesn't, and what to do about it? Journal of Research in Innovative Teaching \& Learning, 10(1), 4-33.

Schrum, L. M. (2000). Guarding the promise of online learning. Education Digest, 66(4), 43-47.

Shea, P. (2020). Introduction to Online Learning volume 24, issue 2, Online Learning Journal, 24(2), $1-5$.

Slater, D. R., \& Davies, R. (2020). Student preferences for learning resources on a land-based postgraduate online degree program. Online Learning, 24(1), 140-161.

Taskiran, A., Gumusoglu, E. K., \& Aydin, B. (2018). Fostering foreign language learning with Twitter: Reflections from English learners. Turkish Online Journal of Distance Education, 19(1), 100-116.

Teng, L. S., Yuan, R. E. \& Sun, P. P. (2020). A mixed-methods approach to investigating motivational regulation strategies and writing proficiency in English as a foreign language contexts. System, 88, 1-11.

Thatcher, A., Wretschko, G., \& Fridjhon, P. (2008). Online flow experiences, problematic Internet use and Internet procrastination. Computers in Human Behavior, 24(5), 2236-2254.

Tiryakioglu, F., \& Erzurum, F. (2011). Use of social networks as an educational tool. Contemporary Educational Technology, 2(2), 135-150. http://dergipark.gov.tr/cet/issue/25724/271433

Veletsianos, G., \& Houlden, S. (2019). An analysis of flexible learning and flexibility over the last 40 years of distance education. Distance Education. 40(4). 454-468.

https://doi.org/10.1080/01587919.2019.1681893

Wan, C. S., \& Chiou, W. B. (2006). Psychological motives and online games addiction: A test of flow theory and humanistic needs theory for Taiwanese adolescents. Cyber Psychology \& Behavior, 9, 317-324.

Wang, C. H., Shannon, D. M., \& Ross, M. E. (2013). Students' characteristics, self-regulated learning, technology self-efficacy, and course outcomes in online learning. Distance Education, 34(3), 302-323.

Wang, J., Spencer, K., \& Xing, M. (2009). Metacognitive beliefs and strategies in learning Chinese as a foreign language. System, 37, 46-56.

Winne, P. H. (2005). Key issues in modeling and applying research on self-regulated learning. Applied Psychology, 54, 232-238.

Waschull, S. B. (2001). The online delivery of psychology courses: Attrition, performance and evaluation. Teaching of Psychology, 28, 143-146.

Watson, J. (2008). Blended Learning: The Convergence of Online and Face-to-Face Education. Promising Practices in Online Learning. North American Council for Online Learning (NACOL).

Wofford, J. C., Goodwin, V. L., \& Premack, S. (1992). Meta-analysis of the antecedents of personal goal level and of the antecedents and consequences of goal commitment. Journal of Management, 18, 595-615. 
Wolters, C. A. (2003). Regulation of motivation: Evaluating an underemphasized aspect of selfregulated learning. Educational Psychologist, 38, 189-205.

Wolters, C., Pintrich, P., \& Karabenick, S. (2003). Assessing academic self-regulated learning. Paper Prepared for the Conference on Indicators of Positive Development: Definitions, Measures, and Prospective Validity. https://www. childtrends. org/wp-content/uploads/2013/05/Child Trends-2003_03_12_PD_PDConfWPK.pdf

Wolters, C. A., \& Rosenthal, H. (2000). The relation between students' motivational beliefs and their use of motivational regulation strategies. International Journal of Educational Research, 33, 801-820.

Wong, L. H., Chai, C. S., \& Aw, P.G. (2017). Seamless language learning: Second language learning with social media. Media Education Research Journal, 25(50), 9-20.

Xing, W. (2019). Exploring the influences of MOOC design features on student performance and persistence. Distance Education, 40(1), 98-113. https://doi.org/10.1080/01587919.2018.1553560

Zhang, J., Lou X., Zhang, H., \& Zhang, J. (2019). Modeling collective attention in online and flexible learning environments. Distance Education, 40(2), 278-301, https://doi.org/10.1080/01587919.2019.1600368

Zhang, D., Zhao, J. L., Zhou, L., \& Nunamaker Jr., J. F. (2004). Can e-learning replace classroom learning? Communications of the ACM, 47(5), 75-79.

Ziegler, K., Hofmann, F., \& Astleitner, H. (2003). Selbstreguliertes lernen und internet [Selfregulated learning and the internet]. Peter Lang.

Zimmerman B. J. (1989). A social cognitive view of self-regulated academic learning. Journal of Educational Psychology, 81(3), 329-339.

Zimmerman, B.J. (2008). Investigation self-regulation and motivation: historical background, methodological developments, and future prospects. American Educational Research Journal, 45(1), 166-183.

Zimmerman, B. J., \& Schunk, D. H. (2008). Motivation. In D. H. Schunk \& B. J. Zimmerman (Eds.), Motivation and self-regulated learning: Theory, research and application (pp. 1-30). Lawrence Erlbaum. 